\title{
Spatiotemporal variation in wetland fish assemblages in the Western Ghats region of India
}

\author{
Archis R. Grubh ${ }^{*}$ and Kirk O. Winemiller \\ Department of Wildlife and Fisheries Sciences, Texas A\&M University, College Station, TX, 77843-2258, USA
}

\begin{abstract}
The Western Ghats region of peninsular India contains high diversity of freshwater fishes that support artisanal fisheries, but no studies to date have investigated fish assemblages of the region's extensive wetlands. This study examined fish population densities and the structure of local species assemblages in pools of the Periyakulam wetland of the Western Ghats. From 2000 to 2001, fishes and local abiotic environmental parameters were surveyed during three periods with contrasting rainfall (dry, major wet, minor wet). We hypothesized that fish density would be higher during the dry season when aquatic habitat is reduced, and that local assemblage structure would be strongly associated with habitat conditions. Total fish densities were higher during the dry season, but the magnitude of seasonal change was relatively low, and this apparently was because changes in water depth were minimal due to operation of sluice gates that control wetland hydrology. Chanda nama, Pseudetroplus maculatus, Rasbora daniconius, and Danio aequipinnatus were dominant species in most habitats during all three seasons. Multivariate ordinations revealed strong associations between assemblage structure and habitats based on vegetation cover. Local assemblages in shallow-vegetated habitats varied seasonally in association with gradients of rainfall and water quality parameters. Spatial variation of local fish assemblages in the Periyakulam wetland appears to be maintained by species-specific habitat selection. Although hydrologic regulation probably has reduced seasonal variation in the structure of local assemblages, seasonal differences still occur and appear to be caused by species differences with regard to periods of reproduction, recruitment, dispersal and habitat selection.
\end{abstract}

Keywords: Aquatic habitat / assemblage structure / community ecology / hydrology / multivariate analysis / ordination / species richness

Résumé - Variation spatio-temporelle des assemblages de poissons des zones humides dans la région des Ghâts occidentaux de l'Inde. La région des Ghâts occidentaux de l'Inde péninsulaire contient une grande diversité de poissons d'eau douce qui soutiennent la pêche artisanale, mais aucune étude à ce jour n'a examiné les assemblages de poissons des vastes zones humides de la région. Cette étude a examiné les densités de populations de poissons et la structure des assemblages d'espèces locales dans les mares de la zone humide de Periyakulam des Ghâts occidentaux. Depuis 2000-2001, les poissons et les paramètres environnementaux abiotiques locaux ont été étudiés pendant trois périodes avec des précipitations contrastées (sèche, grandes pluies humides, petites pluies). Nous avons émis l'hypothèse que la densité de poissons serait plus élevée pendant la saison sèche, lorsque l'habitat aquatique est réduit, et que la structure d'assemblage locale serait fortement associée aux conditions de l'habitat. Les densités totales de poissons étaient plus élevées pendant la saison sèche, mais l'ampleur des changements saisonniers était relativement faible, apparemment parce que les changements dans la profondeur de l'eau étaient minimes en raison de l'exploitation de vannes d'écluse qui contrôlent l'hydrologie des terres humides. Chanda nama, Pseudetroplus maculatus, Rasbora daniconius et Danio aequipinnatus étaient des espèces dominantes dans la plupart des habitats pendant les trois saisons. Les ordinations multivariées ont révélé de fortes associations entre la structure d'assemblage et les habitats basés sur le couvert végétal. Les assemblages locaux dans les habitats à faible végétation variaient selon les saisons en fonction des gradients des précipitations et des paramètres de qualité de l'eau. La variation spatiale des assemblages locaux de poissons dans la zone humide de Periyakulam semble être maintenue par la sélection d'habitats spécifiques à chaque espèce. Bien que la régulation hydrologique ait probablement réduit les variations saisonnières dans la

\footnotetext{
*Corresponding author: archis.grubh@gmail.com
} 
structure des assemblages locaux, des différences saisonnières continuent de se produire et semblent être causées par les différences entre les espèces en ce qui concerne les périodes de reproduction, de recrutement, de dispersion et de sélection de l'habitat.

Mots-clés: : Habitat aquatique / structure d'assemblage / écologie des communautés / hydrologie / analyse multivariable / ordination / richesse spécifique

\section{Introduction}

We investigated the influence of seasonal hydrology on fish assemblage structure in wetland habitats of a floodplain in the Western Ghats region of India. Floodplain ecosystems are temporally and spatially heterogeneous with high biodiversity features that make them particularly useful for studying community ecology (Winemiller, 1990; Jardine et al., 2015; Röpke et al., 2017). Hydrology affects abiotic environmental conditions as well as habitat connectivity that influences metapopulation dynamics of aquatic organisms (Winemiller et al., 2000; Jackson et al., 2013). Stochastic influences on assemblage structure often are strong during high-water periods when there is extensive spatial reshuffling of aquatic organisms (Lowe-McConnell, 1975, 1987; Welcomme, 1985; Thomaz et al., 2007). During low-water periods, high temperatures, hypoxia, desiccation, and/or predation may reduce fish survival in floodplain habitats (Lowe-McConnell, 1975; Junk et al., 1983). In addition, water turbidity has been shown to influence the structure of fish assemblages in tropical floodplain lakes, apparently via effects on foraging efficiency of diurnal predators (Rodríguez and Lewis, 1997).

In wetlands, aquatic vegetation provides prey with refuge from predators that actively pursue them, but can also provide foraging opportunities for fish that probe interstitial spaces for cryptic and slow-moving prey (Downing, 1991; Heck and Crowder, 1991; Chick and McIvor, 1994). Aquatic vegetation creates habitat structural complexity that affords opportunities for spatial niche partitioning (Meals and Miranda, 1991). Predator-prey interactions may differ among macrophyte types (Savino and Stein, 1982; Ryder, 1988; Dionne and Folt, 1991; Lillie and Budd, 1992). Hydrology has a major influence on both the dynamics of aquatic vegetation growth and food webs in floodplain wetlands (Junk et al., 1989; Winemiller, 1996, 2004; Roach and Winemiller, 2015), with patterns of resource exploitation and niche partitioning often changing in response to fluctuations in habitat and resource availability (Winemiller, 1989a; Correa and Winemiller, 2014).

The present study analyzed relationships among seasonally varying environmental variables and fish assemblage structure in the Periyakulam wetland. Prior research on freshwater fishes of the Western Ghats region has revealed patterns of species distribution and abundance at broad spatial scales (Johnson and Arunachalam, 2009; Dahanukar et al., 2011), including studies of fishes inhabiting hill streams (Arunachalam, 2000) and large rivers (Arunachalam et al., 1997a). Little research has been conducted on fish ecology within the region's extensive wetlands (Grubh, 1995; Arunachalam et al., 1997b). We hypothesized that fish abundance and species richness in the Periyakulam wetland would be greater during the annual dry season when aquatic habitats are reduced. We also hypothesized that assemblage structure would differ between habitat categories defined by water depth, substrate and aquatic vegetation, and temporal variation in assemblage structure would correlate with abiotic environmental factors.

\section{Methods}

\subsection{Study area}

The Western Ghats mountain range extends $1600 \mathrm{~km}$ along the west coast of peninsular India and is drained by numerous rivers (Godavari, Chalakudi, Aliyar, Periyar, Chittar, Tamiraparani) (Arunachalam, 2000). The lowland plains of Kanyakumari district (Tamil Nadu state) contain more than 2000 lakes and wetlands, and occur in the drainage basins of the Western Ghats mountains. Annual rainfall in this region is $1.2-1.5 \mathrm{~m}$, with a period of relatively low rainfall from December through March (mean monthly rainfall $35 \mathrm{~cm}$ ) and high rainfall from April through November (mean rainfall $134 \mathrm{~cm}$ ). The wet season is influenced by weather fronts arriving from two regions: a southwest monsoon (major wet season, from April to July) and a northeast monsoon (minor wet season, from August to November). The Kanyakumari wetlands are exploited for irrigation, non-intensive aquaculture, and lotus (Nelumbium speciosum) cultivation (Grubh, 1995). Agriculture mainly consists of rice and bananas. Ponds $>2$ ha are generally stocked with carps native to northern India (e.g., Catla catla, Cirrhinus mrigala, Labeo rohita).

The study system was the Periyakulam wetland near the town of Manavalakurichi in Kanyakumari district $\left(8^{\circ} 10^{\prime}\right.$ $19^{\prime \prime} \mathrm{N}, 77^{\circ} 18^{\prime} 30^{\prime \prime} \mathrm{E}$, Fig. 1). This wetland is one of the largest wetlands in the area (ca. 58 ha) and had not been stocked with carps for over 10 years at the time of our field surveys (Grubh, 2003). Fishing intensity is low and tightly regulated by local authorities. The wetland receives water from reservoirs through canals regulated by sluice gates. Most ponds within the wetland retain water throughout the dry season. Water current was imperceptible in the ponds; substrate was clayey soil to sandy loam, with flat bedrock in some areas. Aquatic macrophytes observed were mostly lotus and lilies (Nymphea sp.) in deeper areas, and diverse submerged, emergent and floating macrophytes in shallow areas (at least 36 species, including Azolla sp., Ceratophyllum dimersum, Eichhornea crassipes, Hibiscus vitifolius, Ipomea aquatic, Jussiaea repens, Kirganelia reticulata, Lantana camara, Limnanthemum indicum, Ludwigia sp., Mimosa pudica, and Paspalum sp.).

\subsection{Field surveys}

Fishes were surveyed in areas near the wetland margin using a seine $(6 \times 1.6 \mathrm{~m}, 2-\mathrm{mm}$ mesh $)$ in shallow areas $(\leq 1 \mathrm{~m}$ depth) and a cast net (6-m diameter, 10-mm mesh) in deeper areas. Two people pulled the seine, and two assisted with 


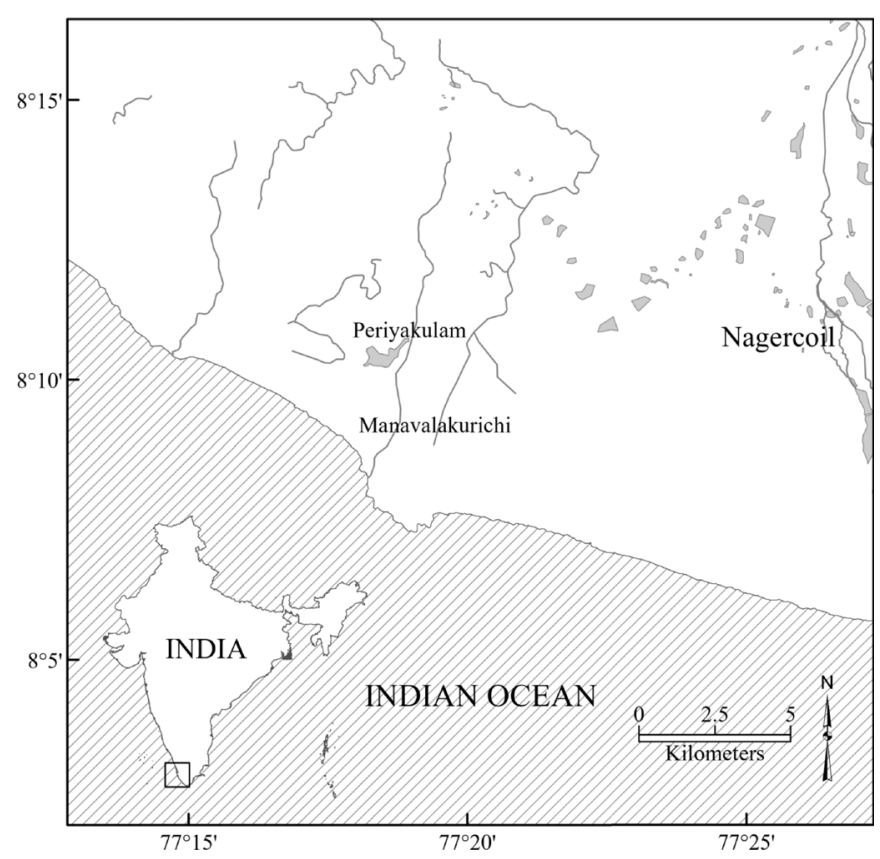

Fig. 1. Location of Periyakulam wetland studied near the southern Western Ghats, India.

release of any rock or wood snags along the bottom. Multiple seine hauls and cast net throws were performed across the shallow and deep regions, within vegetated and non-vegetated rocky habitats (yielding four habitat categories). Replicate samples were combined by habitat type and date, and total seining or cast netting effort for each sample was recorded. At each shallow site on a given survey date, sampling effort was concluded when either $\geq 100 \mathrm{~m}$ had been seined or no additional species were collected after 20 consecutive hauls, whichever occurred first. At each deep site on a given date, minimum of five cast net throws were performed, and then additional throws were made until no additional species were collected. Collected specimens were preserved in $10 \%$ formalin, and then identified, counted, measured for standard length to the nearest $0.1 \mathrm{~mm}$ in the laboratory.

Habitat was classified as (a) shallow-vegetated, (b) shallow-rocky, (c) deep-vegetated, or (d) deep-rocky based on maximum water depth (deep habitats were $>1 \mathrm{~m}$ ) and whether the substrate was dominated by macrophytes rooted in sediments or bare bedrock. The sampling design was unbalanced (total sample size of 41) with respect to habitat categories surveyed during each period: shallow-vegetated areas were surveyed during each month from August 2000 to July 2001, shallow-rocky areas were surveyed monthly from September 2000 to July 2001, and deep-vegetated areas and deep-rocky areas were surveyed monthly from November 2000 to July 2001. Months were grouped based on patterns of regional rainfall: Wet $1=$ Aug-Nov (minor wet season), Dry $=$ Dec-Mar (dry season) and Wet $2=$ Apr-Jul (major wet season) (Fig. 2). During each survey at each site, dissolved oxygen concentration, $\mathrm{pH}$, conductivity and temperature were measured with a multiparameter probe (YSI Instruments) and recorded. Water turbidity was estimated as $1 /$ Secchi depth $(\mathrm{cm})$. Water depth was measured and revealed low variation ( $\leq 60 \mathrm{~cm}$ annually across all sites) due to manipulation of

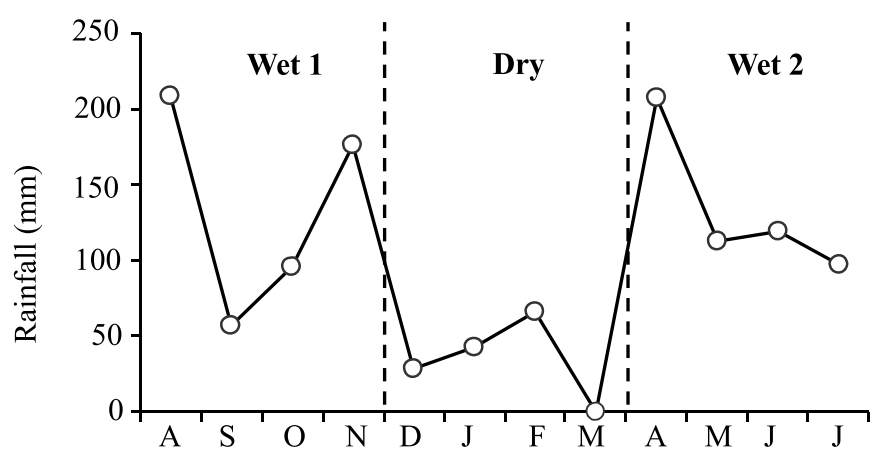

Fig. 2. Rainfall (mm) in Kanyakumari District, Tamil Nadu, India, for the annual cycle August 2000-July 2001.

sluice gates. Rainfall data (monthly average) were obtained from the Tamil Nadu Statistics Service, Kanyakumari District.

\subsection{Data analysis}

Abundance of fish collected from each habitat unit on each date was recorded as catch-per-unit effort (CPUE) based on area surveyed. For seine surveys, the total area was the sum of distances hauled $\times$ width of the net; for cast net surveys, the total area was the number of throws $\times$ the area of the net. For both gear types, CPUE data were standardized as abundance per $50 \mathrm{~m}^{2}$. We considered species CPUE data from the two gear types to be comparable in terms of potential sampling bias; each gear type was deployed in the habitat where it proved to be more effective in capturing fishes (i.e., seine in shallow, marginal areas; cast net in deeper areas). Seasonal variation in species composition was visually represented with a rank abundance plot of the top abundant species. Spatial and temporal relationships among abiotic environmental variables was examined using principal components analysis (PCA), and survey habitats/dates were ordinated according to scores on the first two axes.

Fish assemblage structure was assessed using multivariate methods and species CPUE data. For this analysis, the dataset included only those species that comprised $>0.1 \%$ of total abundance at a given site during a given survey period. Significance of the effect of season (Dry, Wet 1, Wet 2) and habitat type (shallow-vegetated, shallow-rocky, deep-vegetated, deep-rocky) on fish assemblage structure was tested using a two-way analysis of similarity (ANOSIM), and patterns of variation were investigated by ordination plots based on nonmetric multidimensional scaling (NMDS). NMDS was based on Bray-Curtis similarity and CPUE data that were square-root transformed. Those species contributing the most to differences in assemblage structure were identified using the similarity of percentages method (SIMPER). These multivariate analyses were conducted using PRIMER v.7 software (Clarke and Gorley, 2015).

We tested correlations of abiotic factors (temperature, dissolved oxygen, conductivity, turbidity, $\mathrm{pH}$ ) with fish species diversity (Shannon's index) using a generalized linear model (GLM, Gaussian family). Relationships between seasonal and habitat-associated variation in environmental factors and fish assemblage structure were explored using canonical correspondence analysis (CCA). This method 
constrains species and site scores on derived gradients to yield maximum correlation with explained variation among environmental variables. This analysis included all species but emphasized common species variability by downweighting rare species, and was conducted in CANOCO v.5 software (ter Braak and Šmilauer, 2012).

\section{Results}

Surveys of the Periakulam wetland yielded a total of 15970 fish specimens representing 28 species, 13 families and 8 orders. Overall species richness was higher in shallow vegetated habitat and lowest in deep rocky habitat across all seasons. Species richness in shallow vegetated habitats averaged 18 during Dry and Wet 1, and 15.5 during Wet 2 (no test of statistical significance was performed owing to low statistical power from small sample sizes). Seasonal variation in average species richness in shallow rocky habitats was 13 during the Dry season and 9.7 and 7.8 during Wet 1 and 2, respectively. Seasonal variation in species richness was comparatively low in deep vegetated $($ Dry $=9.8$, Wet $1=13$, Wet $2=10)$ and deep rocky (Dry $=9$, Wet $1=10$, Wet $2=7.5$ ) habitats.

Most of the catch (92\%) consisted of 10 abundant species. Four species (Channa striata, Garra mullya, Heteropneustes fossilis, Mastacembelus armatus) were rarely captured. Rankabundance graphs for the 19 most abundant species reveal large interspecific variation within seasons, as well as large intraspecific variation of individual species' ranks between seasons (Fig. 3). Overall, there was low seasonal variation in total abundance of fishes when data were summed across all habitats $\left(F_{2,35}=1.15, P=0.33\right.$; Tabs. A1 and A2). When data were grouped across all seasons, total abundance was higher in shallow compared to deep habitats $\left(F_{1,36}=36.9, P<0.0001\right)$ and higher in vegetated than rocky habitats, however the latter trend was not statistically significant $\left(F_{1,36}=2.15, P=0.15\right.$; Tabs. A1 and A2).

Some species were nearly ubiquitous in habitats we surveyed. For example, Rasbora daniconius was captured throughout the year from all habitat types, but with highest abundance in vegetated habitat. Chanda nama, Etroplus suratensis and Dawkinsia filamentosa occurred in all habitats throughout the year, and largest specimens of these species were captured in deep rocky habitats. Adult size classes of Pseudetroplus maculatus and Xenentodon cancila were common in deep areas with or without vegetation, but juveniles were more common in shallow habitats. Danio aequipinnatus was abundant in vegetated habitats of any depth, and a few individuals were captured from rocky areas. Esomus thermoicos, Horadandia autkorali brittani and Puntius vittatus were common in shallow vegetated habitat, with juvenile size classes abundant during the dry season.

\subsection{Habitat and assemblage structure}

The fish assemblage structure was significantly affected by both season (ANOSIM, $R=0.2, P=0.01$ ) and habitat type (ANOSIM, $R=0.77, P=0.001$; Tab. 1). The NMDS plot shows a separation of shallow and deep habitats, and within those groupings there was separation of vegetated and rocky habitats (Fig. 4). Although ANOSIM revealed a significant effect of
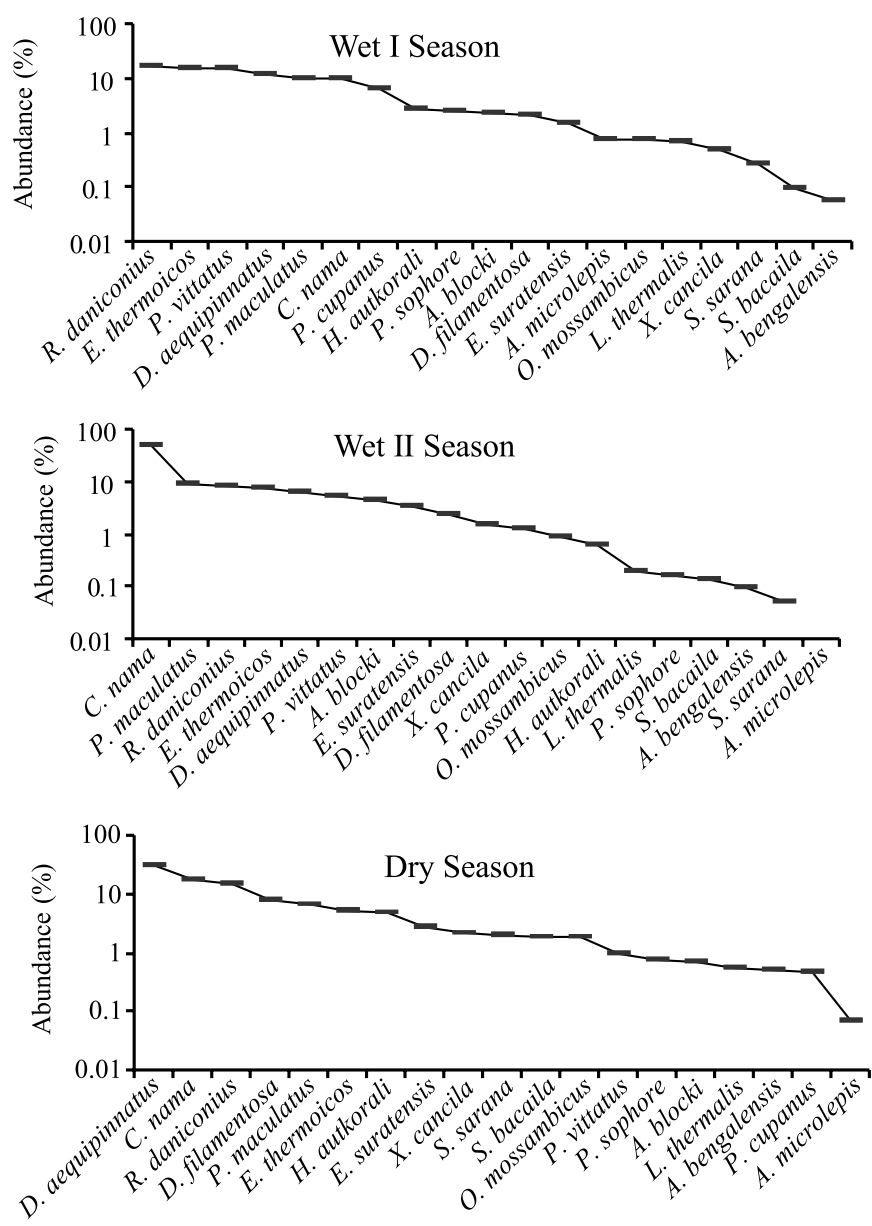

Fig. 3. Rank-abundance graphs for the 19 most common species collected during each of the three seasons.

season on assemblage structure, pairwise comparisons show significant difference only between Wet 1 and Wet 2 . The twoway SIMPER analysis indicated that species contributing assemblage composition during Wet 1 (av. similarity $=63 \%)$ were R. daniconius (15\%) and D. aequipinnatus (14\%), and Ch. nama (12\%). Species contributing to assemblage composition during Wet 2 (av. similarity $=62 \%$ ) were Ch. nama $(25 \%), D$. filamentosa (20\%), and P. maculatus (14\%). Each of the four habitat types had significantly different assemblage composition (ANOSIM), and the greatest dissimilarity (74\%) was observed between shallow vegetated and deep rocky habitats. The dominant species in shallow vegetated habitats were $C h$. nama (15\%), D. aequipinnatus (14\%), and R. daniconius (13\%). Those dominant in deep rocky habitats were $D$. filamentosa $(31 \%), X$. cancila (20\%), and P. maculatus (20\%). Vegetated and rocky deep-water habitats were least different $(41 \%)$ compared to other habitat type comparisons. The deep vegetated habitat was dominated by D. filamentosa (35\%), P. maculatus (22\%), and $R$. daniconius (15\%).

\subsection{Environmental variation and assemblage structure}

Conductivity and turbidity tended to be higher during wet periods than the dry season, and the dry season tended to be 
Table 1. A two-way crossed ANOSIM with season and habitat type comparison with CPUE and square-root transformed fish data. Test showed significant effect of season $(P=0.01)$ with a low global $R$ of 0.2 ; and significant effect of habitat type $(P=0.001)$ with a global $R$ of 0.77 . Differences between categories are reported below.

\begin{tabular}{llll}
\hline Factor & Factor components & $R$ & $P$ \\
& & statistic & value \\
\hline \multirow{4}{*}{ Seasons } & Wet 1 vs. Dry & 0.21 & 0.06 \\
& Wet 1 vs. Wet 2 & 0.34 & 0.02 \\
& Dry $v s$. Wet 2 & 0.08 & 0.16 \\
& & & \\
& Shallow vegetated $v$ s. Shallow rocky & 0.69 & 0.001 \\
& Shallow vegetated $v$ s. Deep rocky & 0.95 & 0.001 \\
Habitat & Shallow vegetated $v s$. Deep vegetated & 0.94 & 0.002 \\
types & Shallow rocky $v s$. Deep rocky & 0.76 & 0.001 \\
& Shallow rocky $v s$. Deep vegetated & 0.86 & 0.001 \\
& Deep rocky $v s$. Deep vegetated & 0.37 & 0.001 \\
\hline
\end{tabular}

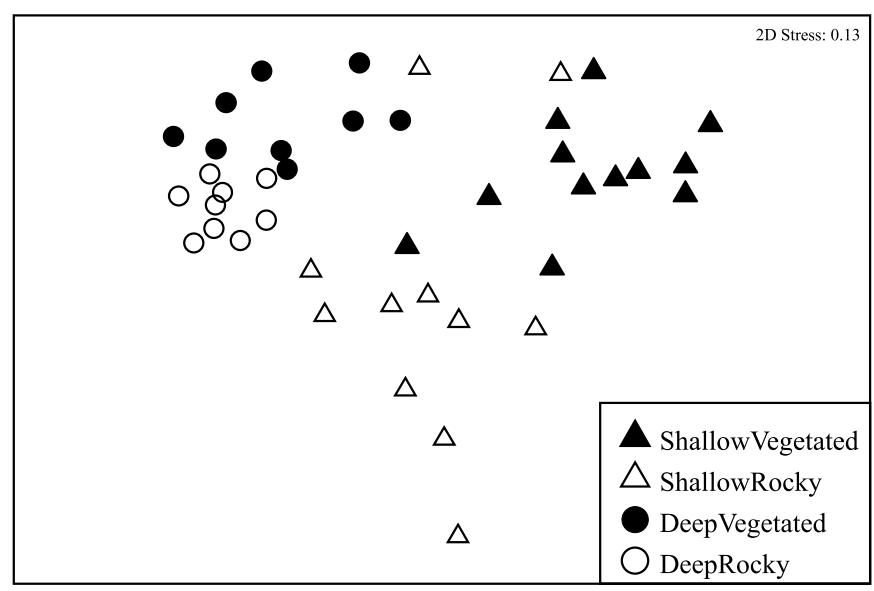

Fig. 4. Nonmetric multidimensional scaling (NMDS) plot comparing fish assemblage structure in four habitat types. CPUE data were square-root transformed; NMDS based on Bray-Curtis similarity; 2D stress $=0.13$.

Table 2. Mean and standard error of abiotic environmental variables measured during different seasons at Periyakulam wetland (turbidity was measured as inverse of Secchi depth).

\begin{tabular}{|c|c|c|c|c|c|c|}
\hline & \multicolumn{2}{|c|}{ Wet 1} & \multicolumn{2}{|c|}{ Wet 2} & \multicolumn{2}{|c|}{ Dry } \\
\hline & Mean & $(\mathrm{SE})$ & Mean & (SE) & Mean & $(\mathrm{SE})$ \\
\hline Temperature $\left({ }^{\circ} \mathrm{C}\right)$ & 28.7 & 0.3 & 28.1 & 0.4 & 29.5 & 0.6 \\
\hline Dissolved oxygen $(\mathrm{mg} / \mathrm{L})$ & 1.8 & 0.5 & 2.7 & 0.3 & 3.1 & 0.2 \\
\hline Conductivity $\left(\mu \mathrm{S} / \mathrm{cm}^{2}\right)$ & 169.5 & 10.3 & 189.2 & 8.6 & 130.9 & 2.6 \\
\hline Turbidity $(1 / \mathrm{cm})$ & 0.0113 & 0.0005 & 0.0116 & 0.0004 & 0.0088 & 0.0002 \\
\hline $\mathrm{pH}$ & 5.9 & 0.7 & 6 & 0.12 & 6.2 & 0.2 \\
\hline Rainfall (cm) & 133.9 & 35.1 & 134 & 25 & 34.4 & 13.7 \\
\hline
\end{tabular}

associated with higher temperature and lower turbidity (Tab. 2, Fig. 5). Seasonal variation in temperature, dissolved oxygen, and $\mathrm{pH}$ was low (Tab. 2). Turbidity was negatively correlated with $\mathrm{pH}$ and temperature; and strongly and positively correlated with rainfall (Tab. 3). The first two PC axes explained $73 \%$ of the total variation in the habitat data (Tab. 4). $\mathrm{PC}$ axis 1 described a gradient of increasing conductivity, $\mathrm{pH}$, and dissolved oxygen associated with declining conductivity and turbidity. PC axis 2 had negative loadings for temperature and positive loadings for dissolved oxygen.

Turbidity and mean monthly rainfall were negatively correlated with species diversity and evenness (Tab. 5). Total fish abundance was positively associated with all environmental variables, although correlations were weak. The GLM model indicated that the fish diversity was significantly affected by abiotic variables (Tab. 6, whole model was significant at $p$-value $=0.006$, and $\mathrm{dF}=5$ ). The specific effect tests that showed significant effect on fish diversity were dissolved oxygen $(P$-value $=0.02)$ and conductivity $(P$ value $=0.01$ ). The nonsignificant variables were temperature, turbidity, and $\mathrm{pH}$. CCA performed on environmental and fish data (Tab. 7) revealed a general trend of seasonal variation in which surveys tended to cluster according to season and habitat type (Fig. 6). In the ordination plot, Wet 2 and deep habitats tended to be associated with higher turbidity and conductivity (upper left quadrat in Fig. 6). Species common in deep habitats during Wet 2 included $X$. cancila, E. suratensis, $D$. filamentosa, and G. guirius. In contrast, vegetated habitats during the dry period tended to have higher temperatures, lower turbidity and conductivity, and other fish species being dominant, including Amblypharyngodon microlepis, and $A$. lineatus. Wet 1 and Wet 2 surveys were more clustered in CCA ordination space than dry season surveys.

\section{Discussion}

Pulsing hydrology is a major driver of ecological dynamics in wetlands worldwide (Lowe-McConnell, 1964, 1975; Welcomme, 1985; Junk et al., 1989; Winemiller, 1996). Despite the fact that sluice gates control water levels in the Periyakulam wetland, seasonal rainfall caused changes in water level (maximum annual variation was $59 \mathrm{~cm}$ ) and associated environmental factors that apparently were sufficient to influence local fish assemblage structure (abundance, evenness, and species richness). As hypothesized, seasonal variation in fish abundance and patterns of habitat use in the Periyakulam wetland were qualitatively similar to those observed in strongly pulsing wetland habitats in the Venezuelan Llanos (Winemiller, 1990, 1996) and Florida Everglades (Loftus and Kushlan, 1987; Chick and McIvor, 
Table 3. Environmental factors correlation matrix (Spearman's $r$ ).

\begin{tabular}{|c|c|c|c|c|c|}
\hline & Temperature & Dissolved oxygen & Conductivity & Turbidity & $\mathrm{pH}$ \\
\hline $\begin{array}{l}\text { Dissolved } \\
\text { oxygen }\end{array}$ & 0.08 & & & & \\
\hline Conductivity & $-0.83^{* *}$ & -0.26 & & & \\
\hline Turbidity & $-0.77^{* *}$ & -0.43 & $0.83^{* *}$ & & \\
\hline $\mathrm{pH}$ & 0.54 & $0.66^{*}$ & $-0.77^{* *}$ & $-0.6^{*}$ & \\
\hline Rainfall & $-0.84^{* *}$ & -0.36 & $0.96{ }^{* *}$ & $0.96{ }^{* *}$ & $-0.72^{* *}$ \\
\hline
\end{tabular}

* Correlation values in bold are significant at $P<0.05$.

*** Correlation values in bold are significant at $P<0.01$.

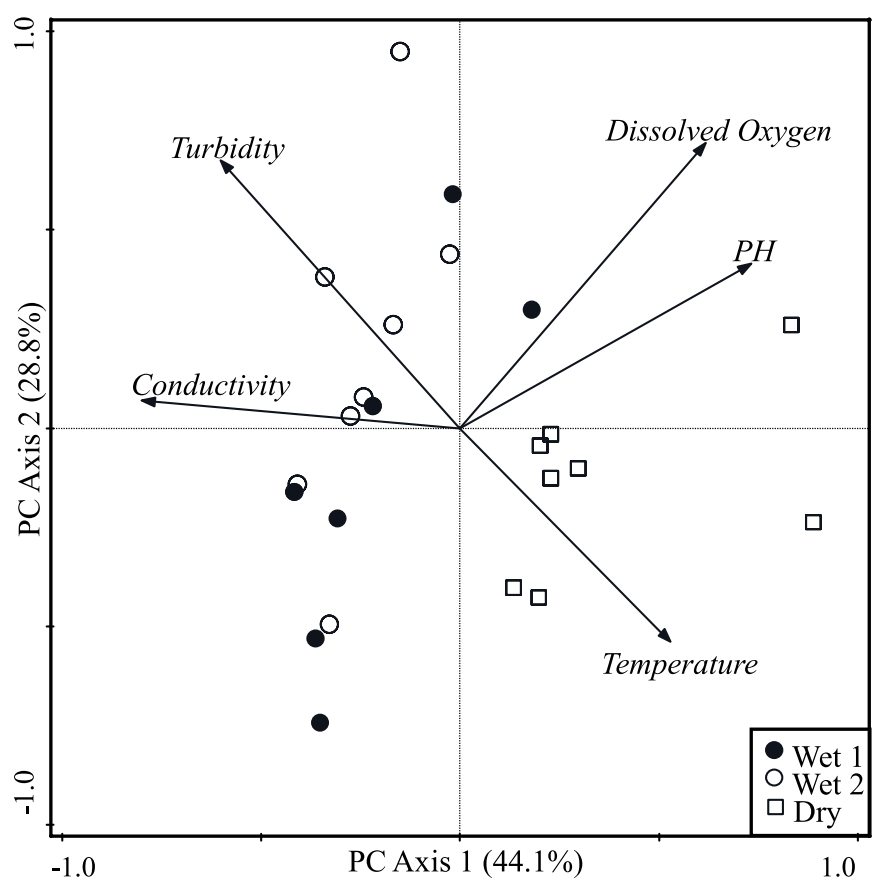

Fig. 5. PCA ordination of survey dates based on analysis of abiotic environmental variables. The first two axes account for $73 \%$ of the explained variation. Length and angle of vectors indicate the strength of the correlation between a given variable and PC axis 1 and 2 .

1994; Loftus and Eklund, 1994; Jordan et al., 1998), but the magnitude of density change was lower at Periyakulam. In the Llanos and Everglades, fish densities often are very high within isolated water bodies during the dry season; during the wet season, aquatic habitat expands and most fish have greater foraging opportunities and grow faster. Everglades fishes revealed species-specific responses to variation in factors such as risk of predation and food availability (Chick et al., 1992; Jordan et al., 1998). In the Periyakulam wetland, Ch. nama, $P$. maculatus, $R$. daniconius, E. thermoicos, and D. aequipinnatus were the five most abundant species. Their dominance was maintained throughout all three seasons.

Although we did not analyze fish size distribution data, it was apparent that juveniles of many species were most abundant within shallow habitats. Small juveniles of several species, including the cichlid $P$. maculatus, were captured throughout the year in shallow habitats. In a study conducted in Sri Lanka, individuals of this species were observed brooding
Table 4. PCA eigenvalues and major axis loadings of abiotic environmental variables. Total variation explained by both PC axes was $72.91 \%$.

\begin{tabular}{lcr}
\hline Habitat variables & PC 1 & PC 2 \\
\hline Temperature & 0.53 & -0.54 \\
Dissolved oxygen & 0.62 & 0.72 \\
Conductivity & -0.8 & 0.07 \\
Turbidity & -0.6 & 0.68 \\
pH & 0.73 & 0.41 \\
Eigenvalue & 0.44 & 0.28 \\
\hline
\end{tabular}

young throughout the year (Ward and Wyman, 1977). In tropical and subtropical habitats with stable or unpredictable hydrology, fish reproduction may be largely aseasonal (Loftus and Kushlan, 1987; Winemiller, 1989b; Jordan et al., 1998). In our study, small fishes with opportunistic life history strategies (sensu Winemiller, 1989b; Winemiller and Rose, 1992), such as $P$. vittatus and $C h$. nama, apparently spawned throughout the year; however, two spawning peaks were observed during December and May following periods of high rainfall. Other species had greater abundance of juvenile size classes during the major wet season (Wet 2), suggesting greater reproductive activity. Although water depth fluctuated relatively little in the Periyakulam wetland, seasonal rainfall could have affected allochthonus nutrient inputs, thereby influencing fish habitat use, food resource availability and reproductive effort. Many tropical fishes have seasonal reproduction that appears to be adaptive in systems with pulsing hydrology (Winemiller, 1989b). For these seasonal spawners, the timing of reproduction may be influenced by subtle environmental cues, such as shifts in day length or water conductivity. Though we did not estimate primary production, flood pulses may release inorganic nutrients from sediments that subsequently support greater production of aquatic macrophytes and algae (Junk et al., 1989). In oligotrophic systems, floodwaters can dilute dissolved inorganic nutrients causing a reduction in net aquatic primary production (Cotner et al., 2006).

In tropical ecosystems with seasonal flood pulses, rising water levels during the wet season induce fishes to leave dryseason refugia and move either laterally onto floodplains or longitudinally upstream to spawn and feed (Lowe-McConnell, 1964; Junk et al., 1989; Winemiller and Jepsen, 1998). This pattern of seasonal movement was not observed in the Periyakulam wetland. We hypothesized that species richness 
A.R. Grubh and K.O. Winemiller: Knowl. Manag. Aquat. Ecosyst. 2018, 419, 35

Table 5. Correlations (Spearman's $r$ ) between assemblage and abiotic environmental variables.

\begin{tabular}{lllcccc}
\hline & Temperature & Dissolved oxygen & Conductivity & Turbidity & $\mathrm{pH}$ & Rainfall \\
\hline Species richness & 0.38 & -0.03 & -0.49 & -0.11 & 0.48 & -0.31 \\
Total abundance & 0.04 & 0.1 & 0.03 & 0.14 & 0.07 & 0.1 \\
Species diversity & 0.47 & 0.27 & -0.57 & $-\mathbf{0 . 6 2}^{*}$ & 0.5 & $-\mathbf{0 . 6 2}$ \\
Species evenness & 0.57 & 0.14 & $-\mathbf{0 . 7 2}$ & -0.47 & $\mathbf{0 . 6 5}^{*}$ & $-\mathbf{0 . 6 1}^{*}$ \\
\hline
\end{tabular}

Correlation values in bold are significant at $P<0.05$. Shannon's species diversity, and Pielou's evenness index were used.

Table 6. Results of a GLM relating fish diversity (Shannon's diversity index) to abiotic environmental factors.

\begin{tabular}{llll}
\hline Species diversity & $\mathrm{dF}$ & Chi square & $P$-value \\
\hline Whole model & 5 & 16.47 & 0.006 \\
Effect tests & & & \\
Temperature & 1 & 0.11 & 0.74 \\
Dissolved oxygen & 1 & 5.80 & $\mathbf{0 . 0 2}$ \\
Conductivity & 1 & 6.49 & $\mathbf{0 . 0 1}$ \\
Turbidity & 1 & 0.78 & 0.38 \\
pH & 1 & 2.52 & 0.11 \\
\hline
\end{tabular}

$P$-values in bold are significant.

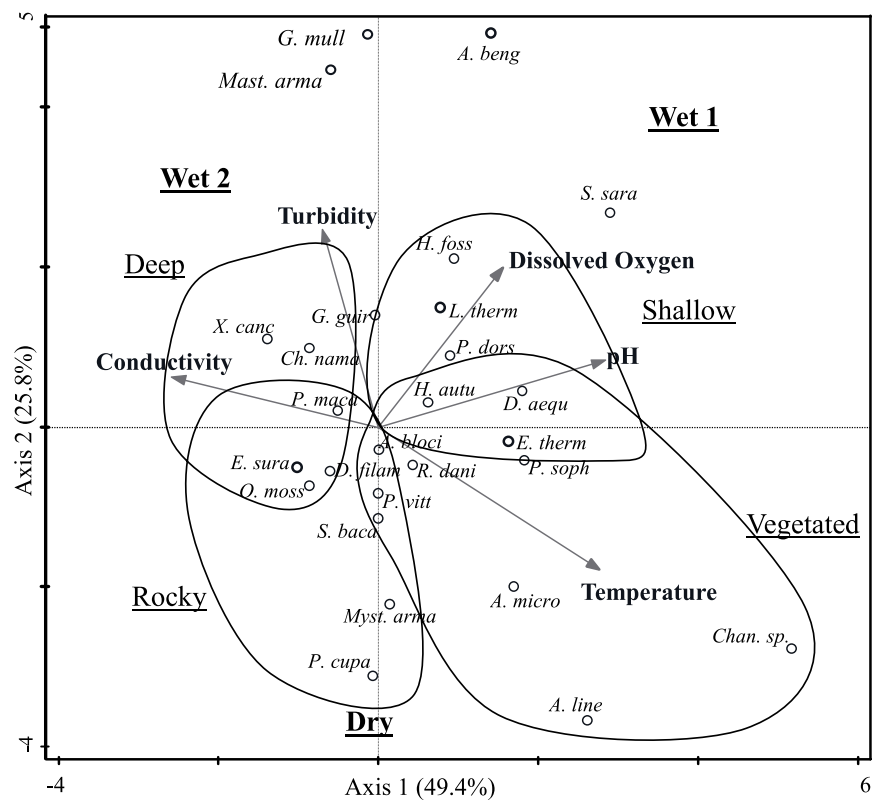

Fig. 6. Ordination of dates for surveys from vegetated habitats based on CCA environmental axes constrained by species CPUE data. The first two axes account for $75 \%$ of the explained fitted variation. Vector length and position indicates the relative influence of the abiotic environmental variable on each axis. Ellipses encompass surveys according to season. Species scores on CCA axes for assemblage structure are given in Table 7.

would be greatest during the dry season when fishes are restricted to smaller volumes of aquatic habitat. Species richness tended to be higher during our dry-season surveys in shallow habitats dominated by vegetation or rocky substrate,
Table 7. Axis eigenvalues and species axis scores for CCA based on species abundance and environmental data in shallow vegetated habitat. The fitted variation explained by first two CCA axes was $75.24 \%$.

\begin{tabular}{lrr}
\hline Species & Axis 1 & Axis 2 \\
\hline Amblypharyngodon microlepis & 1.69 & -1.99 \\
Anguilla bengalensis & 1.40 & 4.94 \\
Aplocheilus blocki & 0.01 & -0.28 \\
Aplocheilus lineatus & 2.61 & -3.67 \\
Chanda nama & -0.87 & 1.00 \\
Channa sp. & 5.17 & -2.77 \\
Danio aequipinnatus & 1.79 & 0.46 \\
Dawkinsia filamentosa & -0.60 & -0.55 \\
Esomus thermoicos & 1.63 & -0.18 \\
Etroplus suratensis & -1.02 & -0.50 \\
Garra mullya & -0.40 & 14.83 \\
Glossogobius guiris & -0.05 & 1.40 \\
Heteropneustes fossilis & 0.94 & 2.11 \\
Horadandia autukorali & 0.62 & 0.31 \\
Lepidocephalus thermalis & 0.77 & 1.50 \\
Mastacembelus armatus & -1.41 & 7.09 \\
Mystus armatus & 0.14 & -2.22 \\
Oreochromis mossambicus & -0.87 & -0.73 \\
Pseudetroplus maculatus & -0.51 & 0.21 \\
Pseudosphromenus cupanus & -0.07 & -3.11 \\
Puntius dorsalis & 0.89 & 0.90 \\
Puntius sophore & 1.82 & -0.42 \\
Puntius vittatus & 0.00 & -0.82 \\
Rasbora daniconius & 0.42 & -0.47 \\
Salmophasia bacaila & -0.01 & -1.14 \\
Systomus sarana & 2.89 & 2.69 \\
Xenentodon cancila & -1.39 & 1.10 \\
Eigenvalue & & \\
\hline & 0.06 & 0.03 \\
\hline
\end{tabular}

but no seasonal trend in species richness was observed for deep habitats.

As predicted, the structure of local species assemblages within the Periyakulam wetland was strongly associated with both habitat and season, with the habitat relationship being stronger. Generally, vegetation, substrate composition, and water depth are expected to affect fish habitat use. Our four habitat categories were widely separated in multivariate ordination space. Species-specific patterns of habitat use probably influence spatial variation in assemblage structure 
within the Periyakulam wetland, but not all species appear to show preferences. Many species were found in both shallow and deep habitats, although their size distributions often differed based on depth or vegetation cover. Some species were essentially restricted to vegetated habitats (e.g. A. microlepis, E. thermoicos, H. autkorali brittani, P. vittatus), and others did not show strong habitat associations (e.g. Ch. nama, E. suratensis, P. maculatus, D. filamentosa, $R$. daniconius, and $X$. cancila). Habitat use patterns varied seasonally for several relatively common species, including Pseudosphromenus cupanus, Puntius sophore, and Salmophasia bacaila. Several species did not yield sufficient samples for inferences about habitat use (Tabs. A1 and A2). Overall, Periyakulam wetland fishes seem to span a gradient of habitat-use ranging from specialists to generalists, a conclusion consistent with findings for Everglades fishes (Chick and McIvor, 1994; Jordan et al., 1998).

Local assemblage structure was correlated with abiotic environmental variables. For example, abundance of one of the most common species, the glassfish $C h$. nama, was strongly correlated with rainfall, water conductivity, and turbidity. Aquatic habitats of the Periyakulam wetland had higher turbidity during Wet 2 , which seemed to result from higher phytoplankton densities, possibly resulting from nutrient loading from runoff. Abundance of the cyprinids $P$. sophore, $P$. vittatus, and A. microlepis was negatively correlated with rainfall, conductivity, and turbidity. During March when no rainfall was recorded and dissolved oxygen concentration was lowest, the cyprinids $R$. daniconius and $P$. vittatus and the paradisefish $P$. cupanus were more abundant in more open (rocky) and deeper habitats. Hypoxic conditions in shallow, sheltered (densely vegetated) habitats could have induced fish to move into open-water areas where there is more water-column mixing from wind action. During the dry season in the Venezuelan Llanos, wetland fishes experience hypoxia derived from decomposition of aquatic macrophytes that die when water recedes (Winemiller, 1990). Fish abundance in the Periyakulam wetland fluctuates to a much lesser degree; nonetheless, several species apparently responded to seasonal changes in physicochemical conditions.

Despite the fact that that several species showed low temporal variation in abundance, others fluctuated to degrees that significantly altered assemblage structure. Fish assemblage structure was strongly associated with seasonal and spatial variation in abiotic environmental parameters, particularly within shallow habitats. Anguilla bengalensis, a catadromous eel, was captured during all three of the seasons. Small size classes were captured in high numbers during September, which indicates recent entry into freshwater by this catadromous fish. The rheophilic suckerfish $G$. mullya was uncommon during most surveys, but was collected in rocky habitats during July near the end of the major wet season. During this same period we observed this species in high numbers in nearby wetlands during surveys to explore regional fish diversity. Although we did not directly observe migration, this species is reported to move upstream to spawn in headwaters, and canals could have provided an avenue for this species to disperse into wetland habitats from adjoining streams.

\section{Conclusion}

The Western Ghats region of peninsular India contains a high diversity of freshwater fishes and regional fish stocks, including those of the Periyakulam wetland, that support small-scale, artisanal fisheries. We hypothesized that fish densities would be higher during the dry season when aquatic habitat is reduced, and that local assemblage structure would be associated with habitat conditions. Fish densities generally were higher during the dry season, but the magnitude of seasonal change was relatively low. A system of canals with sluice gates controls water levels in the wetland, and seasonal fluctuations in water level have been reduced compared to the natural hydrology. Local assemblage structure was significantly associated with water depth and categories of vegetation cover as well as seasons defined by precipitation. Five fish species were dominant in most habitats during all three seasons. Spatial and temporal variation in relative abundance of these and other species likely is influenced by species differences in habitat selection, reproduction, and recruitment. To maintain native fish diversity in the Periyakulam wetland, habitat heterogeneity, including variation in depth and vegetation cover, and seasonal hydrology that to some degree approximates the natural flow regime should be maintained through operation of water control structures.

Acknowledgments. This work was carried out in collaboration with the Institute for Restoration of Natural Environment, Tamil Nadu, India, under the project "Conservation and restoration of biodiversity of tropical freshwater wetlands of Kanyakumari Plains", with support from US Fish and Wildlife Service grant INT/FWS-33. We appreciate the support and technical guidance provided by Dr. Robert Grubh and Shailaja Grubh. We thank Kumudan, Rajesh, Ajitha, Velappan, Kiruba, Jeeva, Carmel, Julian, and Lenin for assistance with fieldwork and data collection. We also thank Mr. I. Anwardeen Indian Forest Service, Tamil Nadu) for providing a scientific export permit, and Dr. Cherian, Dr. Rema Devi and Dr. T.J. Indra of the Zoological Survey of India for providing access to their research facility in Chennai. Dr. John McEachran (TAMU) and David Ferguson (USFWS) provided valuable input during development of the project.

\section{References}

Arunachalam M. 2000. Assemblage structure of stream fishes in the Western Ghats (India). Hydrobiologia 430: 1-31.

Arunachalam M, Johnson R, Johnson JA, Soranam R, Haniffa MA. 1997a. Fish diversity in Chittar River of Western Ghats. Int J Ecol Environ Sci 23: 335-342.

Arunachalam M, Nair KCM, Vijverberg J, Kortmulder K. 1997b. Food and habitat partitioning among fishes in stream pools of a south Indian River. Int J Ecol Environ Sci 23: 271-295.

Chick JH, McIvor CC. 1994. Patterns in abundance and composition of fishes among beds of different macrophytes: viewing a littoral zone as a landscape. Can J Fish Aquat Sci 51: 2873-2882.

Chick JH, Jordan F, Smith JP, McIvor CC. 1992. A comparison of four enclosure traps and methods used to sample fishes in aquatic macrophytes. J Freshw Ecol 7: 353-361. 
Clarke KR, Gorley RN. 2015. PRIMER v.7: user manual/tutorial. Plymouth: PRIMER-E, 296 p.

Correa SB, Winemiller KO. 2014. Niche partitioning among frugivorous fishes in response to fluctuating resources in the Amazonian floodplain forest. Ecology 95: 210-224.

Cotner JB, Montoya JV, Roelke DL, Winemiller KO. 2006. Seasonal variability in benthic and water column productivity in a Venezuelan llanos river. J N Am Benthol Soc 25: 171-184.

Dahanukar N, Raghavan R, Ali A, Abraham R, Shaji CP. The status and distribution of freshwater fishes of the Western Ghats. In: Molur S, Smith KG, Daniel BA, Darwall, WRT, eds. The status and distribution of freshwater biodiversity in the Western Ghats, India. Coimbatore (India): IUCN, Cambridge, UK and Gland, Switzerland, and Zoo Outreach Organisation, 2011, pp. 21-48.

Dionne M, Folt CL. 1991. An experimental analysis of macrophyte growth forms as fish foraging habitat. Can J Fish Aquat Sci 48: $123-131$

Downing JA. The effect of habitat structure on the spatial distribution of freshwater invertebrate populations. In: Bell SS, McCoy ED, Munshinsky HR, eds. Habitat structure: the physical arrangement of objects in space. New York: Chapman and Hall, 1991.

Grubh RB. 1995. Conservation and management of Suchindram kulam wetland in southern India for promotion of agriculture, fishing and ecotourism. Final Technical Report for the Biodiversity Support Program. Nagercoil (India): Institute for Restoration of Natural Environment.

Grubh RB. 2003. Project conservation and restoration of biodiversity of the tropical freshwater Wetlands of Kanyakumari Plains in Peninsular India. Consolidated Technical Report 2000 2002. Nagercoil (India): Institute for Restoration of Natural Environment.

Heck KL, Crowder LB. Habitat structure and predator-prey interactions in vegetated aquatic systems. In: Bell SS, McCoy ED, Mushinsky HR, eds. Habitat structure: the physical arrangement of objects in space. London: Chapman and Hall, 1991, pp. 281-299.

Jackson AT, Adite KA, Roach KA, Winemiller KO. 2013. Fish assemblages of an African river floodplain a test of alternative models of community structure. Ecol Freshw Fish 22: 295-306.

Jardine TD, Bond NR, Burford MA, et al. 2015. Does flood rhythm drive ecosystem responses in tropical riverscapes? Ecology 96: 684-692.

Johnson JA, Arunachalam M. 2009. Diversity, distribution and assemblage structures of fishes in streams of southern Western Ghats, India. $J$ Threat Taxa 1: 507-513.

Jordan F, Babbitt KJ, McIvor CC. 1998. Seasonal variation in habitat use by marsh fishes. Ecol Freshw Fish 7: 159-166.

Junk WJ, Bayley PB, Sparks RE. 1989. The flood pulse concept in river-floodplain systems. Can Spec Publ Fish Aquat Sci 106: $110-127$.

Junk WJ, Soares MGM, Carvalho FM. 1983. Distribution on fish species in a lake of the Amazon River floodplain near Manaus (Lago Camaleão), with special reference to extreme oxygen conditions. Amazoniana 7: 397-431.

Lillie RA, Budd J. 1992. Habitat architecture of Myriophyllum spicatum L. as an index to habitat quality for fish and macroinvertebrates. J Freshw Ecol 7: 113-125.

Loftus WF, Eklund AM. 1994. Long-term dynamics of an Everglades small-fish assemblage. In: Davis SM, Ogden JC, eds. Everglades: the ecosystem and its restoration. Delray Beach (FL): St. Lucie Press, pp. 461-483.
Loftus WF, Kushlan JA. 1987. Freshwater fishes of southern Florida. Bull Fla State Mus, Biol Sci 31: 147-344.

Lowe-McConnell RH. 1964. The fishes of the Rupununi savanna district of British Guiana, Pt. 1. Groupings of fish species and effects of the seasonal cycles on the fish. Zool J Linn Soc 45: $103-144$.

Lowe-McConnell RH. 1975. Fish communities in tropical freshwaters: their distribution, ecology, and evolution. London: Longman.

Lowe-McConnell RH. 1987. Ecological studies in tropical fish communities. Cambridge University Press, Cambridge.

Meals KO, Miranda LE. 1991. Variability in abundance of age-0 centrarchids among littoral habitats of flood control reservoirs in Mississippi. N Am J Fish Manag 11: 298-304.

Roach KA, Winemiller KO. 2015. Hydrologic regime and turbidity influence entrance of terrestrial material into river food webs. Can J Fish Aquat Sci 72: 1099-1112.

Rodríguez MA, Lewis -Jr. WM. 1997. Structure of fish assemblages along environmental gradients in floodplains lakes of the Orinoco River. Ecol Monogr 67: 109-128.

Röpke CP, Amadio J, Zuanon E, Ferreira C, Pereira de Deus C, Winemiller KO. 2017. Simultaneous abrupt shifts in hydrology and fish assemblage structure in a floodplain lake in the central Amazon. Sci Rep 7: 40170.

Ryder CH. 1988. Pipefish foraging: effects of fish size, prey size and altered habitat complexity. Mar Ecol Prog Ser 48: $37-45$.

Savino JF, Stein RA. 1982. Predator-prey interaction between largemouth bass and bluegills as influenced by simulated, submersed vegetation. Trans Am Fish Soc 111: 255-266.

ter Braak CJF, Šmilauer P. 2012. CANOCO reference manual and user's guide software for ordination (version 5.0). Ithaca (NY): Microcomputer Power, 496 p.

Thomaz SM, Bini LM, Bozelli RL. 2007. Floods increase similarity among aquatic habitats in river-floodplain systems. Hydrobiologia 579: $1-13$.

Ward JA, Wyman RL. 1977. Ethology and ecology of cichlid fishes of the genus Etroplus in Sri Lanka: preliminary findings. Environ Biol Fishes 2: 137-145.

Welcomme RL. 1985. River Fisheries. Fisheries Technical Paper 262, FAO, Rome.

Winemiller KO. 1989a. Ontogenetic diet shifts and resource partitioning among piscivorous fishes in the Venezuelan llanos. Environ Biol Fishes 26: 177-199.

Winemiller KO. 1989b. Patterns of variation in life history among South American fishes in seasonal environments. Oecologia 81: 225-241.

Winemiller KO. 1990. Spatial and temporal variation in tropical fish trophic networks. Ecol Monogr 60: 331-367.

Winemiller KO. Factors driving spatial and temporal variation in aquatic floodplain food webs. In: Polis GA, Winemiller KO, eds. Food webs: integration of patterns and dynamics. New York: Chapman and Hall, 1996, pp. 298-312.

Winemiller KO. 2004. Floodplain river food webs: generalizations and implications for fisheries management. In: Welcomme RL, Petr T, eds. Proceedings of the Second International Symposium on the Management of Large Rivers for Fisheries Volume II. Bangkok (Thailand): RAP Publication 2004/16, Regional Office for Asia and the Pacific, pp. 285-309.

Winemiller KO, Jepsen DB. 1998. Effects of seasonality and fish movement on tropical river food webs. J Fish Biol (Suppl A) 267-296. 
A.R. Grubh and K.O. Winemiller: Knowl. Manag. Aquat. Ecosyst. 2018, 419, 35

Winemiller KO, Rose KA. 1992. Patterns of life-history diversification in North-American Fishes-implications for population regulation. Can J Fish Aquat Sci 49: 2196-2218.
Winemiller KO, Tarim S, Shormann D, Cotner JB. 2000. Fish assemblage structure in relation to environmental variation among Brazos River oxbow lakes. Trans Am Fish Soc 129: 451-468.

Cite this article as: Grubh AR, Winemiller KO. 2018. Spatiotemporal variation in wetland fish assemblages in the Western Ghats region of India. Knowl. Manag. Aquat. Ecosyst., 419, 35. 
A.R. Grubh and K.O. Winemiller: Knowl. Manag. Aquat. Ecosyst. 2018, 419, 35

\section{Appendix A}

Table A1. Average abundance of fish species (CPUE transformed) separated by the three seasons collected from shallow habitats at Periyakulam wetland in southern Western Ghats, India.

\begin{tabular}{|c|c|c|c|c|c|c|}
\hline Species & $\begin{array}{l}\text { Shallow } \\
\text { Wet } 1\end{array}$ & Wet 2 & Dry & $\begin{array}{l}\text { Shallo } \\
\text { Wet1 }\end{array}$ & Wet2 & Dry \\
\hline Amblypharyngodon microlepis & 0.3 & & 3.3 & & & \\
\hline Anguilla bengalensis & 5.1 & 0.3 & 0.8 & 0.7 & & \\
\hline Aplocheilus blocki & 2.2 & 12.1 & 6.7 & & 0.8 & 7.3 \\
\hline Aplocheilus lineatus & 0.4 & 0.5 & 2.1 & & & 2.7 \\
\hline Chanda nama & 38.4 & 46.2 & 24.8 & 4.6 & 235.9 & 18.5 \\
\hline Channa sp. & & & 0.5 & 0.7 & & \\
\hline Danio aequipinnatus & 73.2 & 38.0 & 33.9 & & & 42.1 \\
\hline Dawkinsia filamentosa & 7.1 & 3.2 & 3.4 & 26.4 & 3.6 & 5.7 \\
\hline Esomus thermoicos & 12.7 & 50.9 & 49.3 & & & 9.3 \\
\hline Etroplus suratensis & 5.0 & 2.7 & 2.8 & 10.7 & 10.0 & 4.8 \\
\hline Glossogobius guiris & 1.7 & 0.3 & 2.0 & 1.1 & 3.8 & 2.3 \\
\hline Heteropneustes fossilis & 1.8 & & & 5.1 & & \\
\hline Horadandia autukorali & 12.6 & 1.5 & 2.1 & 1.5 & & 30.1 \\
\hline Lepidocephalus thermalis & 1.9 & 2.1 & 3.0 & & & 0.5 \\
\hline Mystus armatus & & 0.5 & 3.0 & & & 0.5 \\
\hline Oreochromis mossambicus & 1.1 & 1.5 & 3.6 & 9.7 & 0.9 & 1.1 \\
\hline Pseudetroplus maculatus & 6.5 & 30.8 & 17.0 & 23.3 & 15.7 & 34.6 \\
\hline Pseudosphromenus cupanus & 1.9 & 3.9 & 37.7 & 0.7 & 1.6 & 3.1 \\
\hline Puntius dorsalis & 0.5 & 1.0 & 0.8 & & & 1.6 \\
\hline Puntius sophore & 2.0 & 0.9 & 11.8 & & & 5.5 \\
\hline Puntius vittatus & 2.3 & 18.5 & 62.5 & & 0.5 & 18.2 \\
\hline Rasbora daniconius & 31.9 & 43.9 & 54.7 & 11.1 & 1.2 & 9.0 \\
\hline Salmophasia bacaila & 3.4 & 0.5 & 0.4 & 8.2 & & 0.5 \\
\hline Systomus sarana & 6.5 & 1.4 & 1.0 & 0.7 & & 1.1 \\
\hline Xenentodon cancila & 4.2 & 0.6 & 1.1 & 3.2 & 7.8 & 2.7 \\
\hline
\end{tabular}


A.R. Grubh and K.O. Winemiller: Knowl. Manag. Aquat. Ecosyst. 2018, 419, 35

Table A2. Average abundance of fish species (CPUE transformed) separated by the three seasons collected from deep habitats at Periyakulam wetland in southern Western Ghats, India.

\begin{tabular}{|c|c|c|c|c|c|c|}
\hline \multirow[b]{2}{*}{ Species } & \multicolumn{3}{|c|}{ Deep vegetated } & \multicolumn{3}{|c|}{ Deep rocky } \\
\hline & Wet 1 & Wet 2 & Dry & Wet1 & Wet2 & Dry \\
\hline Amblypharyngodon microlepis & & 0.5 & 0.5 & & & \\
\hline Chanda nama & 2.8 & 2.1 & 1.8 & 2.7 & 1.2 & 1.5 \\
\hline Danio aequipinnatus & & 1.6 & 6.2 & & & 0.7 \\
\hline Dawkinsia filamentosa & 6.7 & 11 & 15 & 20.8 & 10.9 & 7.8 \\
\hline Esomus thermoicos & & 0.3 & 2.3 & & & \\
\hline Etroplus suratensis & 1.1 & 0.4 & 0.9 & 0.9 & 1.4 & 1 \\
\hline Garra mullya & & & & & 0.2 & \\
\hline Glossogobius guiris & & & & 0.4 & 0.8 & 0.4 \\
\hline Heteropneustes fossilis & 0.4 & & & & & \\
\hline Lepidocephalus thermalis & & & 0.2 & & & \\
\hline Mastacembelus armatus & 0.4 & 0.5 & & & 0.2 & \\
\hline Mystus armatus & 0.4 & & 0.3 & 0.9 & 0.3 & 0.5 \\
\hline Oreochromis mossambicus & & 0.8 & 0.2 & & & 0.4 \\
\hline Pseudetroplus maculatus & 7.1 & 6.4 & 5.3 & 13.3 & 3.9 & 3.8 \\
\hline Pseudosphromenus cupanus & 0.4 & & 0.2 & & & \\
\hline Puntius dorsalis & & 0.3 & 0.3 & 1.3 & 0.3 & 1.4 \\
\hline Puntius sophore & 0.7 & 0.8 & 1.7 & & & \\
\hline Puntius vittatus & & & 0.2 & & & \\
\hline Rasbora daniconius & 0.7 & 15.6 & 4.4 & 0.9 & 3.7 & 0.8 \\
\hline Salmophasia bacaila & 0.7 & 1 & 1.8 & 0.4 & 0.5 & 1.2 \\
\hline Systomus sarana & 2.1 & 1.8 & 2.6 & & & \\
\hline Xenentodon cancila & 2.8 & 3.8 & 0.7 & 4.4 & 5.3 & 5 \\
\hline
\end{tabular}

